Fig. 2 Simplified lithological columns for each site are projected onto a bathymetric and crustal thickness cross-section of the Tyrrhenian Sea (cross-section after Steinmetz, L., Ferrucci, F., Hirn, A., Morelli, C. \& Nicolich, R. Geophys. Res. Lett. 10, 428; 1983). The position of the transect is shown in the insert. Symbols for lithological columns of sites 650 656: (1) nannofos-

sil ooze; (2) nanno-foram or foram-nanno ooze; (3) calcareous ooze; (4) nannofossil chark; (5) nanno-foram or foram-nanno chalk; (6) calcareous chalk; (7) clay/claystone; (8) mud/mudstone (9) sandy mud/sandy mudstone; (10) silt-siltstone; (11) sand/sandstone; (12) gravel; (13) conglomerate; (14) basic igneous; (15) pebbles and red carbonate mud matrix; (16) dolomite; (17) volcanic ash; (18) volcanic lapilli; (19) gypsum; (20) complex transition zone; (21) peridotite.

in a lake. Slumps, debris flows and small faults are common in the sediments deposited during subsidence and stretching of the crust. Subsidence seems to have occurred 1-2 million years later in the south-east (site 652) than further west (site 654).

The geological stages for the past 5 million years were all originally defined on the basis of outcrops around the Tyrrhenian Sea. These stages are now widely used outside the Mediterranean, but some doubt remains about the calibration between the boundaries of stratigraphic zones recognized in the Mediterranean Sea and the biozones of open oceans such as the Atlantic and Pacific oceans or Caribbean Sea. Thus, the third goal of Leg 107 was to recover nearly continuous sediment successions and to calibrate the various techniques used to date marine sediments. Such techniques are based on microfossils, reversals of the Earth's magnetic field, correlations of volcanic ash layers and ratios of stable isotopes contained in the sediments. Drilling at site 653 , where we have successfully obtained two nearly continuous sequences of open marine sediments down to 5 million years old, should be suitable for this purpose.

Leg 107 has touched on many other geological subjects, including evidence for crustal heterogeneity, protrusion of upper canic ash layers, cyclic deposition of Messinian evaporites, the origin of organicrich and metalliferous sediments, the definition of biostratigraphic boundaries and variation of heat flux through the sediment column. The Tyrrhenian Sea is clearly one of the best places for the study of many geological processes. Other areas of the Mediterranean Sea appear to hold similar promise. mantle material, the chronology of vol-

\title{
Parasitology
}

\section{Spurious Babesia antigens}

\section{from F. E. G. Cox}

A promising; approach to the development of a vaccine that would protect cattle against babesiosis has suffered a serious setback with the discovery that what seemed to be the dominant proteins recognized by the serum of babesiosisinfected animals merely reflect a host response to an inflammatory reaction'. Worse still, this discovery is a warning to parallel programmes of vaccine development against other parasitic diseases.

Babesiosis is an important tick-borne protozoal disease of erythrocytes in cattle. affecting several hundred million animals worldwide. Routine immunization can be achieved by vaccination with attenuated strains of the parasite ${ }^{2}$ and there is also evidence that fractionated parasites can confer some protection". The search for more satisfactory vaccines is currently following the procedures pioneered for malaria parasites - the identification of major antigens by immunoblotting techniques using immune sera, the isolation of the relevant messenger RNA, transcription to DNA and eventual cloning. This kind of approach has attracted considerable attention and Australian scientists at the CSIRO laboratories at Indooroopilly in Queensland have over the past few years identified several antigens associated with Babesia bovis-infected erythro- cytes that they now believe may be of host rather than parasite origin!

Calves with no history of babesiosis and with no detectable antibodies against the parasite were injected with turpentine to induce an acute inflammatory response. At the same time sera were collected from cattle immune to $B$. bovis. Nitrocellulose blots of $B$. bovis antigens treated with anti-babesial antisera from immune animals give rise to numerous reaction bands. The dominant bands revealed were of relative molecular mass $120,000-240,000$ and were absent in similar antigen blots treated with control sera. But a similar test with sera from the turpentine-treated animals revealed the same bands. Precautions were taken to ensure that these reactions were not artefacts and the authors conclude that what are apparently $B$. bovis antigens can be detected by sera from animals experiencing a non-specific inflammatory reaction.

The conclusion from these experiments is that these dominant antigens recognized by specific immune sera cannot be of babesial origin, and furthermore that differences in their size range is consistent with their being isoantigens in genetically diverse cattle. Alternatively, these results may indicate interactions between babesias and naturally occurring autoantibodies. The authors suggest that, at the height of parasitaemia, the inflammatory reaction results in the release of acutephase proteins simultaneously with the depression of the immune response to parasite antigens. Thus, the antigens recognized at this stage are those associated with inflammation and not infection.

These results also explain earlier findings that sera from uninfected cattle sometimes produce a positive immunofluorescence in the indirect fluorescence antibody test in which both $B$. bovis-infected erythrocytes and the parasites themselves fluoresce 5 . Overall, the significance of these findings is twofold. First, they pinpoint possible errors in immunodiagnosis; second, and most important, they suggest that immunoblotting techniques may identify spurious candidate antigens for the possible development of vaccines. This warning must be heeded in fields other than babesiosis for there have been reports that sera from uninfected animals react with various antigens of protozoan and helminth origin".

Goodger. B. V.. Wright. I. G. \& Waltishuhi. D. J. Ex perientia 41,1577 (1985).

Callow. L. L. in Blood Parasites of Animuls and Man (eds Miller. L. H. Pino, J. A. \& Mckitiey. J. J.) 121 (Plenum. New York, 1977)

Maboney. D. F. Wright. I. G. \& Goodger. B. V. Prerent vet. Med. 2, $+01(198+4)$

Godion G. N S Ci. Alm. 252(5). 32 (1985)

5. Johmson. L. A. Y. Pearson. R. D.. \& Leatch. L. Aust. vet. J. $49,373(1979)$

6. Grogl, M. \& Kuhn, R. E. Fed. Proc 43, 1+21 (1984)

F. E. (F. Cox is a Professor in the Department of Biophysics, Cell and Molecular Biology. King's College, Strand. London WC2R 2LS. UK 